\title{
Does hyperthermic preconditioning affect the rate of surgical site infection rate and inflammatory reaction in colorectal cancer patients? A prospective randomized clinical trial
}

Wafi Attaallah', Leyla Semiha Șen ${ }^{1}$, Ahmet Özdemir Aktan' ${ }^{1}$ Emel Demiralp Ekșioğlu², Zeynep Eti ${ }^{3}$ Sertaç Ata Güler Asım Cingi ${ }^{1}$

ABSTRACT

Cite this paper as: Attaallah W, Şen LS, Aktan AÖ, Demiralp Ekşioğlu E, Eti Z, Güler SA, et al. Does hyperthermic preconditioning affect the rate of surgical site infection rate and inflammatory reaction in colorectal cancer patients? A prospective randomized clinical trial. Turk J Surg 2018; 34(4): 282-285.

'Department of General Surgery, Marmara University School of Medicine, İstanbul, Turkey 2Department of Immunology, Marmara University School of Medicine, İstanbul, Turkey

${ }^{3}$ Department of Anesthesia, Marmara University School of Medicine, İstanbul, Turkey

Corresponding Author Wafi Attaallah e-mail:drwafi2003@yahoo.com

Received: 08.09.2017 Accepted: 01.11.2017 Available Online Date: 11.09 .2018

CCopyright 2018 by Turkish Surgical Association Available online at www.turkjsurg.com
Objective: Hyperthermic preconditioning has been shown to protect against different insults in experimental studies. However, clinical studies assessing its effects remain limited. The aim of this study was to investigate the effects of hyperthermic preconditioning on the rate of surgical site infection and inflammatory reaction in patients undergoing elective colorectal cancer surgery.

Material and methods: Patients with colorectal cancer, scheduled to undergo elective surgery were enrolled in this prospective randomized study. Patients were randomly assigned to either the hyperthermic preconditioning group or control group. Postoperative superficial and deep surgical site infection were recorded. Blood samples were collected from all the patients in the hyperthermic preconditioning group prior to the application of hyperthermia $12 \mathrm{~h}$ before surgery, immediately prior to surgery, and $4 \mathrm{~h}$ and $24 \mathrm{~h}$ postoperatively. For the control group, blood samples were obtained within the same periods without the application of hyperthermia. Levels of interleukin-1, IL-6, and tumor necrosis factor- $\alpha$ were measured from blood samples.

Results: Twenty patients were randomized to the hyperthermic preconditioning group and 21 to the control group. No significant difference was found in deep or superficial surgical site infection between the groups. No significant difference in the tumor necrosis factor- $\alpha$, interleukin-1, and IL- 6 levels was found in serum samples collected before hyperthermia, during the operation, and postoperatively.

Conclusion: This study showed that hyperthermic preconditioning has no effect on the surgical site infection and cytokine response in patients undergoing elective surgical intervention for colorectal cancer.

Keywords: Colorectal cancer, hyperthermic preconditioning, inflammatory reaction, surgical infection

\section{INTRODUCTION}

Hyperthermic preconditioning (HP) has been shown to be protective against different insults in experimental studies. HP protects against stress conditions in the small intestine, liver, kidney, hippocampus, forebrain, and heart $(1,2)$. Animal studies have shown that hyperthermia protects against intestinal ischemia/reperfusion injury and the lethal effects of endotoxin $(3,4)$ and decreases intestinal permeability in septic mice (5). HP can improve the immune response and subsequently might play a protective role in reducing the severity of fecal peritonitis and sepsis in rats $(6,7)$.

Hyperthermia (HT) induces heat-shock protein (HSP) expression and decreases pancreatic injury. It has also been shown to improve survival in cases of necrotizing pancreatitis (8). The protective effect of HT has been commonly related to the induction of HSPs. Systemic HT is currently used in the treatment of certain malignant diseases (9-11). The positive effect of fever on survival during infections has been well known for several years (12-14). However, despite positive results of experimental studies, the effectiveness of HP in clinical studies remains limited. This prospective randomized study aimed to investigate the effects of HP on surgical site infection (SSI) rates and inflammatory reaction in colorectal cancer patients.

\section{MATERIAL AND METHODS}

Colorectal cancer patients undergoing elective surgery with a curative intent were enrolled in this prospective randomized study at Marmara University Hospital between May 2007 and February 2009. The Marmara University Research Ethics Committee approved the study, and all the subjects provided informed consent before participating in the study.

Patients with colorectal cancer, scheduled to undergo elective surgery with a curative intent, having American Society of Anesthesiologists (ASA) I-II scores were included in the study. Patients with metastatic or disseminated disease, obstruction, and perforation were excluded. Patients not tolerating $\mathrm{HT}$, having ASA scores above II, and those who did not give informed consent were also excluded. The sample size was determined by a power analysis owing to the assumption that HP will decrease infection rate. 
By using an internet randomization table, patients were randomly assigned to either of these groups:

1. HP group: Patients were exposed to heat for $1 \mathrm{~h}$ using a heating blanket $\left(39^{\circ} \mathrm{C}\right) 12 \mathrm{~h}$ before surgery. After the heating procedure was completed, patients were followed until surgery at normal room temperature.

\section{Control group: Patients were kept at room temperature.}

Patients were randomized according to their application dates to our clinic. One of the authors (AC) enrolled participants and assigned them to interventions after generating the random allocation sequence. The participants were blinded after being assigned to interventions according to the randomization table. Duration of postoperative stay in the hospital, number of blood transfusions, and SSI rates were recorded for all the participants. Postoperative complications, including superficial and deep SSI and anastomotic leaks, were also noted. Patients were followed for 30 days after surgery for SSIs. Low molecular weight heparin was administered to all patients for deep venous thrombosis prophylaxis, and its dose was ad-

\begin{tabular}{|c|c|c|c|}
\hline & $\begin{array}{l}\text { Hyperthermic } \\
\text { preconditioning } \\
\text { group } n=20\end{array}$ & $\begin{array}{l}\text { Control } \\
\text { group } n=21\end{array}$ & $\mathrm{p}^{\mathrm{a}}$ \\
\hline Age (years) ${ }^{b}$ & $59(30-88)$ & $69(36-81)$ & $0.074^{c}$ \\
\hline \multicolumn{4}{|l|}{ Gender* } \\
\hline Male & $10(50)$ & $9(43)$ & \multirow{2}{*}{$0.65^{d}$} \\
\hline Female & $10(50)$ & $12(57)$ & \\
\hline \multicolumn{4}{|l|}{$\mathrm{ASA}^{*}$} \\
\hline 1 & $14(70)$ & $13(62)$ & \multirow{2}{*}{$0.6^{d}$} \\
\hline II & $6(30)$ & $8(38)$ & \\
\hline BMI (mean) & $26 \pm 2$ & $28 \pm 5$ & $0,012^{\mathrm{d}}$ \\
\hline$S S I^{*}$ & $6(30)$ & $5(24)$ & $0,87^{d}$ \\
\hline COmorbid disease* & $4(6)$ & $1(5)$ & 0,83 \\
\hline Smoking* & $4(20)$ & $1(5)$ & $0,19^{f}$ \\
\hline Alcohol* & $1(5)$ & $2(10)$ & $1.0^{f}$ \\
\hline $\begin{array}{l}\text { Postoperative stay } \\
\text { in hospital }\end{array}$ & $5.6 \pm 2.7$ & $6 \pm 3$ & $0,66^{d}$ \\
\hline Anastomosis leak* & $0(0)$ & $1(5)$ & $1.0^{f}$ \\
\hline $\begin{array}{l}\text { Postoperative } \\
\text { complications }\end{array}$ & $45(35-240)$ & $59(55-270)$ & $0.07^{c}$ \\
\hline
\end{tabular}

Tumor distance

from anal verge*

\begin{tabular}{|lccc}
$\leq 6 \mathrm{~cm}$ & $24(38)$ & $6(30)$ & $0.3^{\mathrm{d}}$ \\
$>6 \mathrm{~cm}$ & $40(62)$ & $14(70)$ & \\
\hline Blood transfusion* $^{*}$ & $21(33)$ & $1(5)$ & $0,014^{\mathrm{d}}$ \\
\hline SSI risk* & $30(47)$ & $5(25)$ & $0.083^{\mathrm{d}}$ \\
\hline Follow-up period $^{\mathrm{b}}$ & $11(1-20)$ & $6(2-19)$ & $0.21^{\mathrm{c}}$ \\
\hline
\end{tabular}

${ }^{\mathrm{a} C o m p a r i s o n ~ b e t w e e n ~ t w o ~ g r o u p s ~}$

bValues are medians (range)

cMann-Whitney U test

${ }^{\mathrm{d}}$ Chi-square test

et test for independent samples

fFisher's exact test

*; n (\%), "; mean \pm SD

ASA: American Society of Anesthesiologists; BMI: body mass index; HP:

hyperthermic preconditioning; SSI: surgical site infection justed according to body weight. The antibiotics cefazolin and metronidazole were also routinely administered.

Blood samples were collected from all the patients in the HP group prior to the application of hyperthermia $12 \mathrm{~h}$ before surgery, immediately prior to surgery, and $4 \mathrm{~h}$ and $24 \mathrm{~h}$ postoperatively. In the control group, blood samples were obtained within the same periods without the application of hyperthermia. Collected blood samples were centrifuged, and serum samples were stored at $-200^{\circ} \mathrm{C}$ and were later used to measure isnterleukin-1 (IL-1), Interleukin-6 (IL-6), and tumor necrosis factor-a (TNF- $a$ ) levels.

Isnterleukin-1 and IL-6 enzyme-linked immunosorbent assay kits were used according to the manufacturer's recommendations without any modification. A plate reader set at $450 \mathrm{~nm}$ was used to measure optical densities. IL-1, IL-6, and TNF-a levels in the samples were calculated from the standard curve and were multiplied by the dilution factor (expressed as pg/ $\mathrm{mL})$.

The trial was completed after all randomized patients finished the study protocol.

\section{Statistical Analysis}

Data were analyzed using the Statistical Package for Social Sciences (SPSS; version 17.0) statistical software (SPSS, Inc., Chicago, IL, USA). Fisher's exact test and two-tailed chi-square test were used to compare categorical variables (e.g., surgical side infection and gender), whereas the independent two-sample t-test and the Mann-Whitney $U$ test were used to analyze con-

\begin{tabular}{|c|c|c|c|}
\hline & $\begin{array}{l}\text { Hyperthermic } \\
\text { preconditioning } \\
\text { group } n=20\end{array}$ & $\begin{array}{c}\text { Control group } \\
n=21\end{array}$ & $p^{a}$ \\
\hline \multicolumn{4}{|l|}{ TNF levels } \\
\hline $\begin{array}{l}\text { Prior to } \\
\text { hyperthermia }\end{array}$ & $5.76(0.086-727)$ & $6.72(0-68.9)$ & $0.9^{\mathrm{a}}$ \\
\hline $\begin{array}{l}\text { Prior to start } \\
\text { operation }\end{array}$ & $5.85(0.05-497)$ & $5.79(0-154)$ & $1.0^{\mathrm{a}}$ \\
\hline Postoperative $4 \mathrm{~h}$ & $7.0(0.06-727)$ & $6.0(0-136)$ & $0.7^{\mathrm{a}}$ \\
\hline Postoperative $24 \mathrm{~h}$ & $5.0(0.05-417)$ & $5.645(0-96.3)$ & $0.8^{\mathrm{a}}$ \\
\hline \multicolumn{4}{|l|}{ IL-1 levels } \\
\hline $\begin{array}{l}\text { Prior to } \\
\text { hyperthermia }\end{array}$ & $0.60(0.27-2.46)$ & $0.68(0.18-67)$ & $0.18^{\mathrm{a}}$ \\
\hline $\begin{array}{l}\text { Prior to start } \\
\text { operation }\end{array}$ & $0.49(0.17-2.07)$ & $0.52(0.09-26)$ & $0.38^{\mathrm{a}}$ \\
\hline Postoperative $4 \mathrm{~h}$ & $0.66(0.18-45.6)$ & $0.61(0.16-9.8)$ & $0.67^{\mathrm{a}}$ \\
\hline Postoperative $24 \mathrm{~h}$ & $1.12(0.13-3.0)$ & $0.57(0.14-4.05)$ & $0.40^{\mathrm{a}}$ \\
\hline \multicolumn{4}{|l|}{ IL-6 levels } \\
\hline $\begin{array}{l}\text { Prior to } \\
\text { hyperthermia }\end{array}$ & $1.94(0.05-11.2)$ & $6.7(0.3-238)$ & $0.075^{\mathrm{a}}$ \\
\hline $\begin{array}{l}\text { Prior to start } \\
\text { operation }\end{array}$ & $2.0(0.05-21.5)$ & $6.0(0.05-59.8)$ & $0.06^{\mathrm{a}}$ \\
\hline Postoperative $4 \mathrm{~h}$ & $104.0(6.49-238)$ & $\begin{array}{c}10.65 \\
(4.06-238)\end{array}$ & $0.16^{a}$ \\
\hline Postoperative $24 \mathrm{~h}$ & 46.95 (6.9-97) & $13.2(4.06-238)$ & $0.087^{\mathrm{a}}$ \\
\hline
\end{tabular}

aMann-Whitney U Test

TNF-a: tumor necrosis factor- $\alpha$; IL-1: interleukin-1; IL-6: interleukin- 6 
tinuous variables (e.g., age). All statistical tests were two-sided, and $p$-value $<0.05$ was considered to be significant.

\section{RESULTS}

Forty-one patients with colorectal carcinoma were randomized for this study. Twenty patients were randomized to the HP group and 21 to the control group. Age, gender, ASA scores, presence of comorbid disease, alcohol and cigarette consumption, and number of blood transfusions were similar in both groups, while the body mass index was higher in the control group ( $26 \pm 2$ vs $28 \pm 5, p=0.012$ ). Patient demographics are given in Table 1.

Superficial SSI was detected in six patients in the HP group (30\%). In the control group, superficial SSI was noted in five patients (24\%) at the postoperative 30-day follow-up ( $p=0.87$ ). An anastomotic leak was noted in one patient in the control group, while none were detected in the HP group. Duration of the postoperative stay showed similar results $(p=0.66)$.

The median TNF-a levels were 5.76 (0.08-727), 5.85 (0.05-497), $7.0(0.06-727)$, and $5.0(0.05-417) \mathrm{pg} / \mathrm{mL}$ prior to HT, prior to surgery, and at postoperative 4 and 24 hours, respectively. In the control group, the corresponding values were 6.72 (0-68.9), 5.79 (0-154), 6.0 (0-136), and 5.65 (0-96.3) respectively. No statistically significant difference was found among the groups.

The median IL-1 levels were 0.6 (0.27-2.46), 0.49 (0.17-2.07), $0.66(0.18-45.6)$, and $1.12(0.13-3.0)$ prior to HT, prior to surgery, and at $4 \mathrm{~h}$ and $24 \mathrm{~h}$ postoperatively, respectively. In the control group, the corresponding values were 0.68 (018-67.0), 0.52 (0.09-26.0), $0.61(0.16-9.8)$, and $0.57(0.14-4.0)$, respectively. No statistically significant difference was noted.

The median IL-6 levels were 1.94 (0.05-11.2), 2.0 (0.05-21.5), 104.0 (6.49-238), and 46.95 (6.9-97) prior to HT, prior to surgery, and at $4 \mathrm{~h}$ and $24 \mathrm{~h}$ postoperatively, respectively. In the control group, the corresponding values were 6.7 (0.3-238), 6.0 (0.05-59.8), 10.65 (4.06-238), and 13.2 (4.06-238), respectively. No statistically significant difference was found (Table 2). There was no complication or any unintended effect in each group.

\section{DISCUSSION}

In this prospective randomized study, the effect of HP was investigated in patients with colorectal carcinoma treated with a curative intent. No significant difference was found in the rate of SSI among the control and HP groups. In addition, no significant difference was found in TNF- $a$, IL-1, and IL-6 levels among the groups.

Most of the studies reporting the protective effect of HP in various stress states are experimental studies performed in animals, and clinical studies remain limited. However, HT has been more widely used in humans. Systemic HT is currently used in the treatment of certain malignant diseases (9-11), and the positive effect of fever on survival in infections has been well known for several years (12-14). Fever-range hyperthermia has been shown to improve the outcome of serious infections in several animal models $(7,15-17)$. It was suggested that fever may enhance polymorphonuclear leucocyte (PMNL) function, which is the most important defense mechanism against acute bacterial infections. In one rat model, HT was found to increase PMNL counts via the attenuation of apoptosis (18). Furthermore, better leukocyte trafficking was found, which was also associated with tumor regression (19). Therefore, despite insufficient evidence of benefit in humans, HT has been increasingly used in not only complementary or alternative medicine, but also some clinical oncology centers, as an adjunctive treatment to chemoradiotherapy and for the treatment of certain inflammatory diseases.

Previously, induction of heat-shock response was found to preserve organ function and reduce cell injury in myocardial and renal ischemia $(20,21)$. It has been suggested that heat therapy administered before the onset of sepsis may decrease the production of IL-1 and TNF- $a$ and thus might reduce the harmful effects endotoxin release (22). All these positive results were obtained in experimental studies. In contrast to other studies $(7,15-17)$, an animal study performed by our group failed to demonstrate improvement in the rate of survival at $120 \mathrm{~h}$ of intra-abdominal sepsis using HP alone.

Cytokines mediate local inflammatory responses at the site of injury and infection. An exaggerated pro-inflammatory cytokine response to infectious stimuli may result in severe hemodynamic effects (i.e., septic shock) and alteration in the metabolic equilibrium (i.e., increased muscle catabolism and wasting) (23). In this clinical study, no significant difference among the groups in TNF- $a$, IL-1, and IL- 6 levels was found in all the serum samples collected before HP, during the operation, and postoperatively (at $4 \mathrm{~h}$ and the $24 \mathrm{~h}$ ).

The small number of patients is the most important limitation of this study that needs to be acknowledged. Moreover, different temperatures and different preconditioning models may leasd to different results. The duration of $\mathrm{HT}\left(39^{\circ} \mathrm{C}\right)(1 \mathrm{~h}$ and 12 h) before surgery, may not have been the best model. Recent research has shown that HSPs can protect isolated cells from the cytotoxic effects of IL- 1 and TNF- $a$, which are considered to be the chief mediators of sepsis (24-26). In this study, HSPs were not investigated. However, IL-1, IL-6, and TNF-a levels were not significantly different in the control and HP groups, which provides indirect effect on the HSP response.

The pro-inflammatory cytokine response was not different among the groups and at the same time the values obtained varied widely in both groups, contributing to statistical indifference. Superficial SSI was detected in six patients in the HP group (30\%) and in five patients in the control group (24\%) during the postoperative 30-day follow-up. Also, one anastomotic leak was noted. The presence of infection increases proinflammatory cytokines, and high infection rate is probably responsible for the broad variation in cytokine values.

\section{CONCLUSION}

This study showed that HP has no effect on SSI and cytokine response in patients undergoing elective surgical intervention for colorectal cancer.

Ethics Committee Approval: The authors declared that the research was conducted according to the principles of the World Medical Association Declaration of Helsinki "Ethical Principles for Medical Research Involving Human Subjects. 
Informed Consent: Written informed consent was obtained from patient who participated in this study.

Peer-review: Externally peer-reviewed.

Author Contributions: Concept - A.C., A.Ö.A., Z.E., E.D.E.; Design A.C., A.Ö.A., Z.E., E.D.E.; Supervision - A.C., A.Ö.A., W.A., L.S.Ş., S.A.G.; Resource - W.A., A.Ö,A., A.C., L.S.Ş., S.A.G.; Materials - W.A., L.S.Ş., S.A.G., A.C., E.D.E.; Data Collection and/or Processing - W.A. L.S.Ş.,S.A.G., E.D.E.; Analysis and/or Interpretation - W.A., A.C., A.Ö.A., Z.E.; Literature Search - W.A., A.C., A.Ö.A., Z.E., L.S.Ş.; Writing Manuscript - W.A., A.Ö.A., A.C.; Critical Reviews - L.S.Ş., Z.E., E.D.E.

Conflict of Interest: The authors have no conflicts of interest to declare.

Financial Disclosure: This study with project no SAĞ-031/131102 has been supported by Marmara University Scientific Research Projects Commission.

\section{REFERENCES}

1. Sakurai M, Aoki M, Abe K, Sadahiro M, Tabayashi K. Selective motor neuron death and heat shock induction after spinal cord ischemia in rabbits. J Thorac Cardiovasc Surg 1997; 113: 159-164. [CrossRef]

2. Flanagan SW, Ryan AJ, Gisolfi CV, Moseley PL. Tissue-specific HSP70 response in animals undergoing heat stress. Am J Physiol 1995; 268: 28-32. [CrossRef]

3. Stojadinovic A, Kiang J, Smallridge $Y$, Galloway R, Shea-Donohue T. Induction of heat-shock protein 72 protects against ischemia/ reperfusion in rat small intestine. Gastroenterology Aug 1995; 109: 505-515. [CrossRef]

4. Hotchkiss R, Nunally I, Lindquist S, Taulien J, Perdrized G, Karl I. Hyperthermia protects mice against the lethal effects of endotoxin. Am J Physiol 1993; 265: 1447-1457. [CrossRef]

5. Wang $Q$, Hasselgren PO. Heat shock response reduces intestinal permeability in septic mice: potential role of interleukin-10. Am J Physiol Regul Comp Physiol 2002; 282: 669-676. [CrossRef]

6. Ozveri ES, Bekraki A, Cingi A, Yuksel M, Demiralp EE, Yegen BC, et al. The effect of hyperthermic preconditioning on the immune system in rat peritonitis. Intensive Care Med 1999; 25: 1155-1159. [CrossRef]

7. Güllüoğlu BM, Aksoy BS, Ozveri ES, Yüksel M, Demiralp EE, Aktan AO. Optimal timing and temperature for hyperthermic preconditioning in an animal model of fecal peritonitis. J of Investigative Surg 2002; 15: 117-124. [CrossRef]

8. Grise K, Kim F, McFadden D. Hyperthermia induces heat-shock protein expression, reduces pancreatic injury and improves survival in necrotizing pancreatitis. Pancreas Aug 2000; 21: 120-125. [CrossRef]

9. Bone RC. American College of Chest Physicians/Society of Critical Care of Medicine Consensus Conference:definitions for sepsis and organ failure and guidelines for the use of innovative therapies in sepsis. Crit Care Med 1992; 20: 864 -874 [CrossRef]

10. Robins HI, Sielaff KM, Storer B, Hawkins MJ, Borden E. Phase I trial of human lymphoblastoid interferon with whole body hyperthermia in advanced cancer. Cancer Res 1989; 49: 1609-1615

11. Trautman JA. Artificial fever therapy:a discussion of its management and a report of the complications of treatments. Arch Phys Ther 1942; 23: 196-206.

12. Covert JB, Reynolds WW. Survival value of fever in fish. Nature 1977; 267: 43-46. [CrossRef]

13. Kluger MJ. Fever role of pyrogens and cryogens. Physiol Rev 1991; 71: 93-127. [CrossRef]

14. Kluger MJ, Ringler DH, Anver MR. Fever and survival. Science 1975; 188: 166-168. [CrossRef]

15. Hotchkiss R, Nunnally I, Lindquist S, Taulien J, Perdrizet G, Karl I. Hyperthermia protects mice against the lethal effects of endotoxin. Am J Physiol 1993; 265: R1447-R1457. [CrossRef]

16. Koh Y, Lim CM, Kim MJ, Shim TS, Lee SD, Kim WS, et al. Heat shock response decreases endotoxin-induced acute lung injury in rats. Respirology 1999; 4: 325-330. [CrossRef]

17. Villar J, Ribeiro SP, Mullen JB, Kuliszewski M, Post M, Slutsky AS. Induction of the heat shock response reduces mortality rate and organ damage in a sepsis-induced acute lung injury model. Crit Care Med 1994; 22: 914-921. [CrossRef]

18. Chen HW, Hsu C, Lue SI, Yang RC. Attenuation of sepsis-induced apoptosis by heat shock pretreatment in rats. Cell Stress Chaperones 2000; 5: 188-195. [CrossRef]

19. Chen Q, Fisher DT, Kucinska SA, Wang WC, Evans SS. Dynamic control of lymphocyte trafficking by fever-range thermal stress. Cancer Immunol Immunother 2006; 55: 299-311. [CrossRef]

20. Donnelly TJ, Sievers RE, Vissern FL, Welsh WJ, Wolfe CL. HSP induction in rat hearts:a role for improved myocardial salvage after ischemia and reperfusion? Circulation 1992; 85: 769-778. [CrossRef]

21. Perdrizet GA, Heffron TG, Buckingham FC, Salciunas PJ, Gaber $A O$, Stuart FP, et al. Thistlethwaite JR Stress conditioning: anovel approach to organ preservation. Curr Surg 1989; 46: 23-26.

22. Hotchiss R, Nunnally I, Lindquist S, Taulien J, Perdrizet G, Karl I. Hyperthermia protects mice against the lethal effects of endotoxin. Am J Physiol 1993; 265: 1447-1457.

23. Badar V, Stephen F. Lowry. Schwartz's priciples of surgery. Ninth edition, Chapter 2. p. 20.

24. Jaatlela M, Saksela K, Saksela E. Heat shock protectes WEH $1 \pm 164$ target cells from the cytolysis by tumor necrosis factors alpha and beta. Eur J Immunol 1989; 19: 1413-1417. [CrossRef]

25. Larrick JW. Antibody inhibition of the immunoinflammatory cascade. J Crit Care 1989; 4: 211-221. [CrossRef]

26. Margulis BA, Sandler S, Eizirik D, Welsh N, Welsh M. Purified heat shock protein hsp 70 into rat pancreatic islets as protection against interleukin $1 \mathrm{~b}$-induced impaired $\mathrm{b}$ cell function. Diabetes 1991; 40: 1418-1422. [CrossRef] 